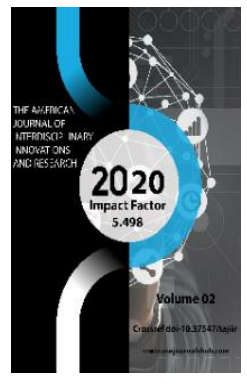

Copyright: Original content from this work may be used under the terms of the creative commons attributes 4.0 licence.

\section{Policy Of Repression: Difficult And Complex Years For The People}

Jumaniyazov Damir Qu'atbaevich

Doctor Of Philosophy In History (PhD), Karakalpak State University, Uzbekistan

Jangabaev Jumabek Jalgasbaevich

Trainee Teacher Of The Department Of History Of Uzbekistan And Karakalpakstan, Uzbekistan

\title{
ABSTRACT
}

The article examines the innocent victims who were selfless representatives of the Karakalpak people, such as Ubaydulla Baoetdinov (Khan Maksim), Kutlymuratbiy (Bala biy), Inayat bolis Niyazov, Ollo'r Dustnazarov, Kasym Auebaev, Kasim Aoezov in the Bolshevik government during policy of repression. It is estimated that $70 \%$ of the representatives of the Karakalpak Autonomous Region were arrested under the name "public enemy", as a result of which the population became afraid and the policy of totalitarianism was intensified.

\section{KEYWORDS}

Counter-revolution, policy of repression, "public enemy", Ajina bridge, slander, memory book.

\section{INTRODUCTION}

As we study the history of our nation, one of the most complex and difficult periods in our history was the policy of repression pursued by the Soviet government in the 1920 s and 1940 . In this way, the Soviet government tried to destroy any opposition, any dissent in government policy, any critical opinion, any prominent, leading political statesman of any nation, all forms of democracy. It could not have been otherwise under the totalitarian 
regime. The policy of repression was carried out in Uzbekistan, as well as in all the republics of the former Soviet Union, including Karakalpakstan.

According to some sources, 3,778,000 people were charged with counter-revolutionary activities in the former Soviet Union, of which 768,098 (20\%) were shot dead, 2,369,000 were imprisoned for various periods, 765,000 were deported and relocated [1.18].

There were several waves of repression in Karakalpakstan between 1920 and 1940. This period left tragic traces in the history of the Karakalpak people and took away from us the most advanced, educated and courageous children of the people.

The policy of repression in Karakalpakstan began with the establishment of Soviet power. The reason was that the forced establishment of the Bolshevik government led to popular uprisings against them in 1917-1922. The major leaders of the revolt, such as Ubaydulla Bao'etdinov (Khan Maqsym), Kutlymuratbiy (Bala biy), Inayat bolys Niyazov, Ibrayim Adilov, Seytnazar Pirnazarov and others, were arrested. Some of them were shot, the others were exiled. This was the first policy of repression in Karakalpakstan [3.239].

\section{MATERIALS AND METHODS}

The next stage of the policy of repression in Karakalpakstan was carried out in 1928-1930. During this period, local statesman, on the one hand, and scholars, who played an important role in the spiritual life of the people, on the other, were repressed. In 1929, the former head of the Karakalpak Autonomous Regional Court, Abdijalil Ismetullaev, and the participants of the uprising led by Barlykbay
Bolis Nurymov (Takhtakopir uprising) were severely punished. Alshansky, the OGPU's deputy plenipotentiary in Kazakhstan, was in charge of punishing them. 232 people were arrested as defendants. 104 of them were found guilty under Article 58, Sections 1-2-4 of the Criminal Code of the RSFSR, 52 were sentenced to death, and the rest to various terms of imprisonment. The leaders of the uprising Abdijalil Ismetullaev, former deputy chairman of the Chimbay district executive committee Matkarim Bekanov, Askar Urumbaev, Khojakhmet Ernazarov, Orazymbet Ayteshev, Najim Ibragimov, Pakhratdin Munaydarov (former chairmen of the volost executive committee) and the others were shot. [3. 241]. In addition, in accordance with the decision of the meeting of the Plenipotentiary Representation of the OGPU "Trinity" in Kazakhstan, Article 58, Parts 1-2, Article 59, Part 1 of the Criminal Code of the RSFSR, 18 of the 49 people were sentenced to death on January 3, 1930, the sentence was performed on the same day in Kungrad [1.20].

Another tragic aspect of the repressions of 1928-1930 was aimed at destroying the spiritual wealth of our people. During these years, in connection with the transition to the Latin alphabet in our country, the Bolsheviks tried to destroy all books and manuscripts written in Arabic script. The scribes and Eshan were arrested. Among them Inayat Eshan Bakhaoatdinov, Khalila Akhun Atauliev, Pakhratdin Eshan Munaydarov, Tansyk Khoja Orumbayev, Karimberdi Akhun Nurullaev were found guilty under Article 58, Part 2 of the Criminal Code of the RSFSR and sentenced to death [3. 241]. In addition, Idris Ishan Shyrazatdin oglu, llyas Ishan Idiris oglu, Najim Ishan Tajetdinov, O'ayis Ishan, Nurilla Akhun 
Pirlepes oglu and other scholars of the Karakum Eshan dynasty, who gained prestige among the peoples of the whole Turan Valley, were unjustly severely punished.

Another mass repression in Karakalpakstan took place in 1936-1938. The center charged the leaders of the local party-Soviet bodies with being called "Trotsky-Bukharans," "counterrevolutionaries," and "nationalists." Secretaries of regional committees, heads of departments, the chairman of the Council of Ministers, his deputies, people's commissars, first secretaries of district party committees, heads of district executive committees, $70 \%$ of their deputies were arrested as "public enemy."

\section{RESULT AND DISCUSSION}

One of such brave Karakalpak boys was Olloyor Dustnazarov, who was the first secretary of the Karakalpak Autonomous Region Party Committee in 1924-1925. He was arrested by the NKVD on January 25, 1935 in Moscow on charges of "contact with counterrevolutionary organizations" and sentenced to 10 years in prison. However, on November 10, 1937, the "Trinity" group of the NKVD in the Leningrad regional administration reconsidered the case of O. Dustnazarov and sentenced him to be accused of being "public enemy", and the verdict was executed on December 8, 1937 [2. 418-419].

On December 13, 1938, a trial was held in Tashkent against 50 Karakalpak officials. 40 of them were convicted under Articles 57 1b, 58, 63, 64, 67 of the Criminal Code of the UzSSR and sentenced to death. The verdict was executed in Tashkent on the same day and they were buried without a shroud in the depths of the Ajina Bridge. Each of the others was sentenced to 10-15 years in prison [1. 21]. Among them are Kasym Auezov, Abio Kudabaev, Koptileo Nurmukhammedov, Oteniyaz Bekimbetov and regional secretaries I. Aliev, K. Baltaev, K. Alimov, K. Allabergenov, People's Commissars T. Nizamatdinov, A., Bekmuratov, Chairman of the Supreme Court A. Pirnazarov and others who took an active part in the restoration of statehood and the development of our national culture were shot and buried on top of each other.

According to some estimates, 10,000 people were persecuted in Karakalpakstan between the first half of 1934-1939. In 1939-1940, the NKVD of the USSR fabricated 168 "counterrevolutionary" criminal cases involving false witnesses and slander and handed them over to court. [3. 245].

On May 1, 2001, the Presidential Decree "On the establishment of the Day of Remembrance of the Victims of Repression" was adopted. It was emphasized that under the totalitarian regime millions of innocent people died, many families were ruined, and many children were separated from their parents. In order to restore truth and justice, to respect the courage of our oppressed compatriots, to instill in our compatriots, especially the younger generation, a sense of respect for their memory, the annual Day of Remembrance of the Victims of Repression is set for August 31.

\section{CONCLUSION}

Work in this direction continued, and the Karakalpak branch of the Fund for the Memory of the Martyrs of the Republic of Uzbekistan took measures to establish the names of the 
boys who died for the freedom of the Motherland and the people in Soviet times. On the basis of sources in the central and republican archives, the names of about 5 thousand repressed were established. In 2003, based on this information, the monograph "Political Victims in the History of the Republic of Karakalpakstan" was published.

Indeed, we have no right to forget our compatriots, who were persecuted on false accusations when they served the good of the country under the Soviet totalitarian regime, they will forever remain in our hearts.

\section{REFERENCES}

1. Babashev Sh., Victims of repression without punishment. Nukus. 2007.

2. New history of Uzbekistan, book II. Toshkent., 2000

3. New history of Karakalpakstan. Nukus. 2003 